\title{
Correlation Between Neutrophil-lymphocyte Count Ratio and Procalcitonin in Sepsis and Septic Shock
}

\author{
Jonathan, ${ }^{1,2}$ Erwin Pradian, ${ }^{2}$ Ardi Zulfariansyah ${ }^{2}$ \\ ${ }^{1}$ Kefamenanu General Hospital, East Nusa Tenggara, Indonesia, ${ }^{2}$ Department of Anesthesiology and Intensive Care \\ Faculty of Medicine Universitas Padjadjaran/Dr. Hasan Sadikin General Hospital Bandung
}

\begin{abstract}
Sepsis is one of the leading causes of death in patients with infection. Procalcitonin is one of the laboratory parameters that is used to differentiate between thesystemic inflammatory responses caused by pathogens and non-pathogens. Neutrophil-lymphocyte count ratio (NLCR) is one of the simple laboratory parameters used. The purpose of this study was to investigate the correlation between NLCR and procalcitonin for sepsis and septic shock patients. A cross-sectional prospective correlational analysis study was perfromed on 36 sepsis and septic shock patients admitted to the Intensive Care Unit of Dr. Hasan Sadikin Bandung General Hospital during September 2017-May 2018. Statistical analysis was performed using Rank Spearman's and Mann Whitney test. Both procalcitonin and NLCR increased in sepsis and septic shock patients. Procalcitonin level was significantly different in sepsis and septic shock groups $(p<0.05)$, albeit insignificant difference in NLCR ( $>0.05)$. NLCR was significantly higher in gram positive bacteria patient group $(\mathrm{p}<0.05)$; however, the difference was not seen for procalcitonin level $(\mathrm{p}>0.05)$. Correlation test found a significant positive correlation between SOFA score and procalcitonin $(\mathrm{r}=0.557$ and $\mathrm{p}<0.01)$ and no correlation between SOFA score and NLCR $(\mathrm{r}=0.117$ and $\mathrm{p}>0.05)$. There was no correlation between NLCR and procalcitonin for sepsis and septic shock patients ( $\mathrm{r}=0.122$ and $\mathrm{p}>0.05$ ). Therefore, no correlation was found between NLCR and procalcitonin for sepsis and septic shock patients.
\end{abstract}

Key words: Neutrophil-lymphocyte count ratio, procalcitonin, sepsis, SOFA score

\section{Korelasi antara Rasio Hitung Neutrofil-Limfosit dan Prokalsitonin pada Pasien Sepsis dan Syok Sepsis}

\begin{abstract}
Abstrak
Sepsis merupakan salah satu penyebab kematian terbanyak pada pasien infeksi. Pemeriksaan prokalsitonin merupakan salah satu parameter untuk membedakan bahwa respons inflamasi sistemik disebabkan oleh patogen atau non-patogen. Parameter laboratorium lain yang lebih sederhana adalah rasio hitung neutrofillimfosit (neutrophil-lymphocyte count ratio/NLCR). Tujuan penelitian ini mengetahui korelasi antara NLCR dan prokalsitonin pada pasien sepsis dan syok sepsis. Penelitian analisis korelasional prospektif ini dilakukan dengan desain potong lintang terhadap 36 pasien sepsis dan syok septik yang dirawat di ICU Rumah Sakit Dr. Hasan Sadikin Bandung periode September 2017-Mei 2018. Analisis statistik menggunakan Uji Rank Spearman dan Mann Whitney. Kadar prokalsitonin dan NLCR meningkat pada pasien sepsis dan syok septik. Kadar prokalsitonin berbeda secara signifikan pada kelompok sepsis dan syok septik $(\mathrm{p}<0,05)$, perbedaan tidak terlihat untuk NLCR $(p>0,05)$. NLCR secara signifikan lebih tinggi pada bakteri gram positif daripada bakteri gram negatif $(p<0,05)$, perbedaan tidak terlihat pada kadar prokalsitonin $(\mathrm{p}>0,05)$. Uji korelasi menunjukkan korelasi positif yang signifikan antara skor SOFA dan prokalsitonin $(r=0,557 ; \mathrm{p}<0,01)$ dan tidak terdapat korelasi antara skor SOFA dengan NLCR ( $\mathrm{r}=0,117 ; \mathrm{p}>0,05)$. Tidak terdapat korelasi antara NLCR dan prokalsitonin pada pasien sepsis dan syok septik $(r=0,122 ; p>0,05)$. Simpulan: tidak terdapat korelasi antara NLCR dan prokalsitonin pada pasien sepsis dan syok septik.
\end{abstract}

Kata kunci: Prokalsitonin, rasio hitung neutrofil-limfosit, sepsis, skor SOFA

Corresponding Author: Jonathan Susanto, Kefamenanu General Hospital, East Nusa Tenggara, Jalan Letjen Suprapto, Kefamenanu Tengah, Kabupaten Timor Tengah Utara, East Nusa Tenggara, Indonesia, Email: jonathansusanto2003@gmail.com 


\section{Introduction}

Sepsis is a syndrome of physiological, pathological, and biochemical abnormalities induced by infections. Sepsis is the most common cause of mortality, especially in critical patients at a non-cardiac intensive care unit, with about $50 \%$ patients with septic shock have died. Furthermore, patients who recover from sepsis often have long-term physical, psychological, and cognitive disabilities with significant impacts on social and health care. ${ }^{1}$

Sepsis and bacteremia are one of the causes of morbidity and mortality worldwide and a delay and misdiagnosis of these conditions will increase the mortality rate. ${ }^{2}$ The mortality rate in patients with septic shock has increased 7\% per hour within the first 6 hours in the case of delayed antibiotic administration. Surviving Sepsis Campaign (SSC) recommended that blood culture should be done immediately to determine the source of infection. ${ }^{3}$ Extensive research is needed to investigate the right biomarker serum for these conditions, such as interleukin-6 (IL6), interleukin-8 (IL-8), interleukin-10 (IL-10), $\mathrm{C}$-reactive protein (CRP), and procalcitonin. Most studies have concluded that IL-6, IL-8, IL-10, and CRP were not adequately specific to differentiate between the systemic inflammatory response syndrome which is caused by infection and noninfection. ${ }^{3}$

Procalcitonin examination is one of a reliable parameters to determine if the systemic inflammation response syndrome is caused by a pathogenic or non-pathogenic cause. In a normal situation, procalcitonin concentration in blood is very low. In sepsis, systemic infection, and severe inflammation condition, the level of procalcitonin increase significantly along with other cytokines. Procalcitonin production in inflammation is associated with bacterial endotoxin and inflammation cytokine (TNF, IL-6, IL-1b) production. The procalcitonin detected in inflammation is not produced by thyroid C cells. The possible production site of procalcitonin in inflammation is ileum or pulmonary neuroendocrine cells. There is a correlation between increasing procalcitonin concentration and systemic inflammatory response caused by bacterial infection. ${ }^{3}$

Neutrophil-lymphocyte count ratio is one of the simple laboratory parameters for systemic infection patients. Neutrophilia and lymphopenia in acute infection make the neutrophil-lymphocyte count ratio increase in patients with bacteremia. Studies showed that neutrophil-lymphocyte count ratio is superior to conventional infection markers in patients with bacteremia. $^{4}$

This study aimed to investigate the correlation between neutrophil-lymphocyte count ratio and procalcitonin in patients with sepsis and septic shock.

\section{Methods}

This was a cross-sectional prospective correlational analysis won patients with sepsis and septic shock who received care in the ICU ward of Dr. Hasan Sadikin General Hospital Bandung, Indonesia, from September 2017 to May 2018. The inclusion criteria applied was patients with sepsis and septic shock with age ranged from 18-65 years old who were admitted to ICU of Dr. Hasan Sadikin General Hospital. Patients with autoimmune disease, malignancy or cancer, trauma, organ transplant, pancreatitis, rhabdomyolysis, and immunodeficiency (HIV/ AIDS) as well as patients who underwent chemotherapy and pregnant patients were excluded from the study.

After receiving ethical clearance from the Health Research Ethic Committee of Dr. Hasan Sadikin General Hospital Bandung under the ethical clearance number LB.04.01/A05/ EC/297/X/2017, sampling was performed cross-sectionally according to the inclusion and exclusion criteria. Data recorded were age, sex, infection source, microbiology culture, type of gram bacteria, procalcitonin level, leukocytes level, neutrophil-lymphocyte count ratio, and SOFA score. Data were analyzed and described using a table according to variables identified during the study and Mann Whitney comparative test and Rank Spearman correlation test were used to describe the association between study variables.

\section{Results}

Study results showed that there were more sepsis patients than those with septic shock with pulmonary infection as the most frequently seen infection (20 of 36 patients) followed by abdominal infection (8 of 36 patients) infection. Most of the sepsis or septic shock conditions carried primarily gram negative bacteria (23 of 36 patients) with Acinetobacter sp. (9 cases) as the most common bacteria. The most common gram positive bacteria identified in this study 
Table 1 General Characteristics of Septis and Septic Shock Patients Undergoing Treatment at Intensive Care Unit of Dr. Hasan Sadikin Hospital Bandung

\begin{tabular}{|c|c|}
\hline Variables & Statistic \\
\hline \multicolumn{2}{|l|}{ Age (year) } \\
\hline Mean (SD) & $41.5(16.22)$ \\
\hline \multicolumn{2}{|l|}{ Sex } \\
\hline Male (n) & 19 \\
\hline Female (n) & 17 \\
\hline \multicolumn{2}{|l|}{ Type of sepsis } \\
\hline Sepsis (n) & 21 \\
\hline Septic shock (n) & 15 \\
\hline \multicolumn{2}{|l|}{ Leucocytes (cell/uL) } \\
\hline Mean (SD) & $16.524(8.347)$ \\
\hline Median (Range) & $16.735(4.000-44.480)$ \\
\hline \multicolumn{2}{|c|}{ Procalcitonin level (ng/mL) } \\
\hline Mean (SD) & $26.99(29.44)$ \\
\hline Median (Range) & $11.96(2.18-81.00)$ \\
\hline \multicolumn{2}{|c|}{ Neutrophil-lymphocyte count ratio } \\
\hline Mean (SD) & $21.72(13.87)$ \\
\hline Median (Range) & $17.4(5.13-48.00)$ \\
\hline \multicolumn{2}{|l|}{ Infection source } \\
\hline Pulmonary (n) & 20 \\
\hline Abdominal (n) & 8 \\
\hline Oral cavity (n) & 4 \\
\hline $\operatorname{Limb}(\mathrm{n})$ & 4 \\
\hline \multicolumn{2}{|c|}{ Culture and gram stain result (n) } \\
\hline Gram positive & 7 \\
\hline Streptoccocus sp. & 4 \\
\hline Stafilococcus sp. & 1 \\
\hline Enterococcus sp. & 2 \\
\hline Gram negative & 23 \\
\hline Acinetobacter sp. & 9 \\
\hline Escherechia sp. & 4 \\
\hline Pseudomonas sp. & 3 \\
\hline Klebsiella sp. & 3 \\
\hline Enterobacter sp. & 2 \\
\hline Proteus sp. & 1 \\
\hline Providencia sp. & 1 \\
\hline Sterile & 6 \\
\hline
\end{tabular}

Table 2 Comparison between Procalcitonin Level and Neutrophil-Lymphocyte Count Ratio by Type of Sepsis and Gram Bacteria

\begin{tabular}{lcccc}
\hline \multicolumn{1}{c}{ Variables } & n & Mean & SD & p-value \\
\hline Procalcitonin level (ng/mL) & & & & \\
Sepsis & 21 & 16.81 & 21.84 & $0.042^{*}$ \\
Septic shock & 15 & 41.25 & 33.36 & \\
Neutrophil-lymphocyte count ratio & & & & \\
Sepsis & 21 & 20.84 & 14.26 & 0.465 \\
Septic shock & 15 & 22.95 & 13.69 & \\
Procalcitonin level (ng/mL) & 7 & 15.73 & 8.36 & 0.737 \\
Gram positive bacteria & 23 & 27.31 & 31.55 & \\
Gram negative bacteria & & & & \\
Neutrophil-lymphocyte count ratio & 7 & 32.75 & 10.33 & $0.048^{*}$ \\
Gram positive bacteria & 23 & 20.62 & 14.35 & \\
Gram negative bacteria & &
\end{tabular}

Note: Comparative test using Mann Whitney test. differencial were stated as *significant if $\mathrm{p}<0.05$; **verysignificant if $\mathrm{p}<0.01$ 
Jonathan, et al: Correlation Between Neutrophil-lymphocyte Count Ratio and Procalcitonin in Sepsis and Septic Shock

Table 3 Correlation between SOFA Score, Procalcitonin Assessment, and NeutrophilLymphocyte Count Ratio in Patients with Sepsis and Septic Shock

\begin{tabular}{lcc}
\hline \multicolumn{1}{c}{ Correlation } & r & p value \\
\hline SOFA score vs procalcitonin & 0.557 & $0.000^{* *}$ \\
SOFA score vs neutrophil-lymphocyte count ratio & 0.117 & 0.498 \\
Procalcitonin vs neutrophil-lymphocyte count ratio & 0.122 & 0.477 \\
\hline
\end{tabular}

Note: Correlation using Rank Spearman's test were stated as *significant if $\mathrm{p}<0.05$, **very significant if $\mathrm{p}<0.01$

was Streptococcus sp. (4 cases; Table 1).

The statistic analysis showed a significant difference in the procalcitonin level between sepsis and septic shock patients with a mean value of 16.81 for sepsis patients and 41.25 for septic shock patients. The statistical analysis results also showed a significant difference between the neutrophil-lymphocyte count ratio in gram positive and negative bacteria $(\mathrm{p}<0.05$; Table 2).

Statistical analysis results showed that there was a very significant correlation between SOFA score and procalcitonin level $(\mathrm{p}<0.01)$ but no correlation was found between SOFA score and neutrophil-lymphocyte count ratio ( $>0.05$; Table 3). No significant correlation was identified between procalcitonin assessment and neutrophil-lymphocyte count ratio, with a correlation value of 0.122 and $p$ value of 0.477 ( $>0.05$; Table 3).

\section{Discussion}

Several studies have been conducted to investigate the use of biomarker assessment in diagnosis, prognosis, severity determination, and monitoring of sepsis. Procalcitonin assessment and neutrophil-lymphocyte count ratio is one of the biomarkers which can be used in addition to other conventional biomarkers (leukocyte count, CRP, interleukin). Procalcitonin is a protein with 116 amino acid and a calcitonin hormone precursor produced by thyroid $\mathrm{C}$ cells. Procalcitonin has different profiles to other sepsis markers currently used as it has C-reactive protein (CRP), lactate, or numerous proinflammatory cytokines (IL6 , IL-8). ${ }^{5}$ Gram positive and gram negative bacterial invasion caused procalcitonin level to increase. Procalcitonin is released as a response to bacterial infection. Increased procalcitonin level is observed within six to twelve hours after bacterial infection and will decrease into half every day if the infection is successfully controlled by the body's immune system or antibiotics. $^{6}$

In this study, an increase in the procalcitonin level in patients with sepsis and septic shock was observed. The mean value of procalcitonin in this study was 26.99 with value ranged from 2.18 to 81 (Table 1). Results showed a significant difference in procalcitonin levels between patients with sepsis and septic shock with $\mathrm{p}=0.042(\mathrm{p}<0.05$; Table 2) and there is a correlation between procalcitonin level and SOFA score with a value of $\mathrm{r}=0.557 \quad(\mathrm{p}<0.01$; Table 3). Previous studies showed a correlation between procalcitonin level increase and the systemic inflammatory response caused by bacterial infection. Studies showed that systemic inflammatory response correlates with the severity of systemic inflammation; hence the procalcitonin level is higher in septic shock patients $(>10 \mathrm{ng} / \mathrm{mL})$ when compared to septic patients $(>2 \mathrm{ng} / \mathrm{mL}) .{ }^{5}$ Other studies also suggested that higher procalcitonin level and SOFA score correlates positively to the mortality rate. ${ }^{7-9}$

In this study, gram positive bacteria produced a mean procalcitonin value of 15.73 (8.36) while the gram negative bacteria produced a value of 27.31 (31.55; Table 2). Although the study results presented that patients with septic shock triggered by gram negative bacteria and gram positive bacteria had a procalcitonin level up to $80 \mathrm{ng} / \mathrm{mL}$ and $33 \mathrm{ng} / \mathrm{mL}$, respectively, comparative test results did not revealed any difference in procalcitonin level between gram positive and negative bacteria septic patients with $p=0.737$ ( $p>0.05$; Table 2). This is different from results from previous studies where gram negative bacteria produced a higher procalcitonin mean value compared to gram positive bacteria. This condition may occur as the three previous studies did not differentiate patients in sepsis and septic shock, in which septic shock conditions produced a higher procalcitonin level. The underlying mechanism for procalcitonin production for each pathogenic bacteria is not fully clear. Different interactions between gram positive and negative bacteria with host cells, molecular pattern, and receptors 
involved in different inflammatory cytokine production may cause the difference. ${ }^{10-12}$

An increase in neutrophil-lymphocyte count ratio with a mean value of neutrophil-lymphocyte count ratio of 21.72 with a range of 5.13 to 48 was observed (Table 1). One of physiological responses of the body's immune system to systemic inflammation is increased levels of neutrophil and decreased levels of leukocyte. Changes in the dynamics and regulation of apoptosis occur during systemic inflammation. A delay in neutrophil apoptosis will prolong the lifetime of neutrophils in metabolizing toxic substances. ${ }^{13}$ The opposite happens in lymphocyte apoptosis which will reduce inflammation. ${ }^{14}$ An activated inflammatory cytokine release can cause tissue damages and organ dysfunction. Lymphocyte apoptosis results in suppression of adaptive immune response which causes the patient to be susceptible to nosocomial infection and opportunistic microbial invasion which potentially induce an advanced systemic inflammatory reaction. ${ }^{13,14} \mathrm{~A}$ previous study has suggested that neutrophillymphocyte count ratio is a simple assessment which can predict bacteremia better than the conventional infection marker. ${ }^{4}$

There was an insignificant difference of neutrophil-lymphocyte count ratio between sepsis and septic shock patients in this study ( $p>0.05$ ) with a mean value of 20.84 in sepsis patients and 22.95 in septic shock patients (Table 2) and there was no correlation between neutrophil-lymphocyte count ratio and SOFA score or level of severity (Table 3). Previous studies on the use of neutrophil-lymphocyte count ratio as a severity predictor; type of sepsis (sepsis or septic shock); and septic patient mortality risk have shown contradicting results. A previous study showed an increase of septic patient mortality risk along with neutrophil increase, lymphocyte decrease, and neutrophillymphocyte count ratio increase. ${ }^{15}$ On the contrary, another study showed no statistically significant association between neutrophillymphocyte count ratio and mortality in sepsis patients. ${ }^{16}$ A study conducted on 65 septic patients showed that procalcitonin was superior to neutrophil-lymphocyte count ratio to assess the severity of sepsis patients. The study also showed there is no difference in neutrophillymphocyte count ratio either on sepsis or severe sepsis patients. ${ }^{17}$

A significant difference was seen in the neutrophil-lymphocyte count ratio between gram positive and negative bacteria $(\mathrm{p}<0.05$;
Table 2). Gram positive bacteria had a mean neutrophil-lymphocyte count ratio of 32.75 , which was higher compared to gram negative bacteria of 20.62 (Table 2). A study on a sepsis patient with gram positive bacterial infection has shown a decrease in NK cells that is more persistent compared to gram negative bacteria. These cells are an important component of the native immune system and do not require specific antigen stimulation. These are also a part of the first line body's immune system and a subtype of lymphocyte cell. This indicates stronger activation of NK cells in gram positive bacterial infection which requires a well-organized body response to eliminate. A study has observed faster normalization of $\mathrm{T}$ cell lymphocytes and its derivatives $\left(\mathrm{CD}^{+}, \mathrm{CD}^{+}\right)$in gram negative bacteria when compared to gram positive bacteria. Lymphocyte cell death which is activated in the tissues will lead to the a slower recovery of circulating lymphocyte $\mathrm{T}$ cells in sepsis patients with gram positive bacterial infection. ${ }^{18}$ Another study suggested that gram positive bacteria causestronger suppression of lymphocytes when compared to gram negative bacteria and that the NK cells are the most affected in sepsis patients. ${ }^{19}$ A stronger lymphocyte suppression in gram positive bacterial infection, more persistent lymphocytopenia in gram positive bacterial infection, and faster normalization of $\mathrm{T}$ lymphocyte cells and its derivative $\left(\mathrm{CD}^{+}, \mathrm{CD} 8\right)$ in gram negative bacterial infection may be the cause of a higher neutrophil-lymphocyte count ratio in gram positive bacteria infection. ${ }^{18,19}$

No significant correlation between procalcitonin assessment and neutrophillymphocyte count ratio was observed in this study, with a correlation value of 0.102 and $p$ value of 0.477 ( $p>0.05)$.

For many years, many studies have been conducted to investigate the use of biomarker assessment in the diagnosis, prognosis, severity, and monitoring of sepsis. Procalcitonin assessment and neutrophil-lymphocyte count ratio is one of the biomarkers which can be used other than other conventional biomarkers (leukocyte count, CRP, interleukin). Several studies have presented that there is a significant correlation between procalcitonin assessment in the diagnosis, prognosis, severity, and monitoring of sepsis. ${ }^{1,3,5}$ A previous study on 65 septic patients showed that although neutrophillymphocyte count ratio increases in sepsis patients, procalcitonin is superior to neutrophillymphocyte count ratio to evaluate the severity of sepsis. ${ }^{17}$ Findings in this study are consistent 
with those of previous studies that procalcitonin has a significant correlation to patient's severity either classified according to sepsis or septic shock or using SOFA score with $\mathrm{p}<0.05$ (Table 2 and 3). Some other studies on neutrophillymphocyte count ratio resulted in contradictory findings ${ }^{15-17,20}$ The current study showed that the neutrophil-lymphocyte count ratio assessment was not significantly different between sepsis and septic shock patients and no no correlation between neutrophil-lymphocyte count ratio and SOFA score was observed (Table 2 and Table $3)$. The difference in procalcitonin result and neutrophil-lymphocyte count ratio with the type of sepsis (sepsis/septic shock) and degree of severity of sepsis (SOFA score) may be one of the causes of the lack of correlation between procalcitonin and neutrophil-lymphocyte count ratio in this study.

Comparative test results in this study show that gram positive bacteria had a neutrophillymphocyte countratio of 32.75, which was higher than in gram negative bacterial infection (20.62) $\mathrm{p}<0.05$. This is different from procalcitonin level which shows no difference in both gram positive or negative bacteria (Table 2).

Procalcitonin will increase rapidly within 2 hours after stimulation, reaches its peak in 12 hours and decreases in half each day when the infection is under control.5,17 In this study, no difference in procalcitonin level was seen between gram positive and negative bacterial infection. On the other hand, a different condition was observed in neutrophils and lymphocytes, where neutrophils will be in circulation during 7-10 hours before migration. ${ }^{17}$ Lymphocyte cells as a native and adaptive immune system will be suppressed during sepsis. Lymphocyte suppression is stronger and more persistent in gram positive bacterial infection. This is also true for the $\mathrm{T}$ lymphocyte cell normalization. which may be the reason why the neutrophillymphocyte count ratio was higher in this study (32.75) when compared to gram negative bacterial infection (20.62). ${ }^{18}$ The difference in immune response between neutrophillymphocyte count ratio and procalcitonin in relation to the type of gram bacteria that causes infection may explain why there is no correlation between the two assessments. An advanced study on each variable with a bigger sample size and periodic sampling approached is warranted.

Some previous studies which compared the specificity and sensitivity between neutrophillymphocyte count ratio and procalcitonin in sepsis or bacteremia patients showed that procalcitonin is more sensitive ad specific in diagnosing sepsis and bacteremia compared to neutrophil-lymphocyte count ratio. A study on 65 sepsis and septic shock patients with a neutrophil-lymphocyte count ratio cut-off of 9.05 and procalcitonin of $98.2 \%$ presented the specificity of neutrophil-lymphocyte count ratio of $50 \%$ and procalcitonin of $75 \%{ }^{17}$ Another study on bacteremia detection with a neutrophil-lymphocyte count ratio cut-off point of $>10$ resulted in $77.2 \%$ sensitivity and $63 \%$ specificity. ${ }^{4}$ A lower sensitivity and specificity of neutrophil-lymphocyte count ratio may be another reason for the lack of linear correlation between neutrophil-lymphocyte count ratio and procalcitonin although both increase in sepsis patients. Therefore, no linear correlation is identified between procalcitonin and neutrophillymphocyte count ratio in sepsis and septic shock patients.

\section{References}

1. Seymour CW, Liu VX, Iwashyna TJ. Assessment of clinical criteria for sepsis for the third international consensus definitions for sepsis and septic shock (sepsis-3). JAMA. 2016;315(8):762-74.

2. Gurol G, Ciftci IH, Terzi HA, Atasoy AR, Ozbek A, Koroglu M. Are there standardized cutoff values for neutrophil-lymphocyte ratios in bacteremia or sepsis?. J Microbiol Biotechnol. 2014;25(4):521-5.

3. Carr JA. Procalcitonin-guided antibiotic therapy for septic patients in the surgical intensive care unit. J Intensive Care Med. 2015;3(1):1-8.

4. de Jager CP, van Wijk PT, Mathoera RB, de Jongh-Leuvenink J, van der Poll T, Wever PC. Lymphocytopenia and neutrophillymphocyte count ratio predict bacteremia better than conventional infection markers in an emergency care unit. Crit Care. 2010;14(5):R192.

5. Meisner M. Update on procalcitonin measurements. Ann Lab Med. 2014;2014(34):263-73.

6. Schuetz P, Chiappa V, Briel M. Procalcitonin algorithms for antibiotic therapy decisions a systematic review of randomized controlled trials and recommendations for clinical algorithms. JAMA. 2011;171(15):1322-31.

7. Miro M, del Valle GS, Agámez G, García PP, Martínez HE, Olivas E. Correlation between SOFA score and procalcitonin blood levels 
in peritonitis patients: 12AP3-4. Eur J Anaesthesiol. 2011;28(Suppl 48):173.

8. Singh SP, Jhinger MK, Kaur S, Singla N, Singh. JP. Interrelationship between pct levels and sofa score in sepsis patients-a hospital based study. IJCMR. 2017;4(6):1297-300.

9. Matsumura Y, Nakada TA, Abe R, Oshima $\mathrm{T}$, Oda S. Serum procalcitonin level and sofa score at discharge from the intensive care unit predict post-intensive care unit mortality: a prospective study. PLoS One. 2014;9(12):e114007.

10. Leli C, Ferranti M, Moretti A, Al Dhahab ZS, Cenci E, Mencacci A. Procalcitonin levels in gram-positive, gram-negative, and fungal bloodstream infections Disease Markers. 2015;2015:1-8.

11. Watanabe Y, Oikawa N, Hariu M, Fuke R, Seki M. Ability of procalcitonin to diagnose bacterial infection and bacteria types compared with blood culture findings. Int J Gen Med. 2016;9:325-31.

12. Li S, Rong H, Guo Q, Chen Y, Zhang G, Yang J. Serum procalcitonin levels distinguish gramnegative bacterial sepsis from gram-positive bacterial and fungal sepsis. J Res Med Sci. 2016;21:39-53.

13. Chen X-h, Yin Y-j, Zhang J-x. Sepsis and immune response. World J Emerg Med. 2011;2(2):88-92.

14. Silva FPd, Nizet V. Cell death during sepsis: integration of disintegration in the inflammatory response to overwhelming infection. Apoptosis. 2009;14(4):509-21.

15. Liu X, Shen Y, Wang H, Ge Q, Fei A, Pan S. Prognostic significance of neutrophil-tolymphocyte ratio in patients with sepsis: a prospective observational study. Mediators Inflamm. 2016;2016:1-8.

16. Salciccioli JD, Marshall DC, Pimentel MA, Santos MD, Pollard T, Celi LA, et al. The association between the neutrophil-tolymphocyte ratio and mortality in critical illness: an observational cohort study. Crit Care. 2015;19(1):1-13.

17. Arif SK, Rukka ABS, Wahyuni S. Comparison of neutrophils-lymphocytes ratio and procalcitonin parameters in sepsis patient treated in Intensive Care Unit Dr. Wahidin Hospital, Makassar, Indonesia. J Med Sci. 2017;17(1):17-21.

18. Holub M, Kluckova Z, Helcl M, Prihodov J, Rokyta R, Beran 0. Lymphocyte subset numbers depend on the bacterial origin of sepsis. Clin Microbiol Infect. 2003;9(3):20211.

19. Forget P, Khalifa C, Defour J-P, Latinne D, Van Pel M-C, De Kock M. What is the normal value of the neutrophil-to-lymphocyte ratio? BMC Research Notes. 2017;10(1):12-5.

20. Riché F, Gayat E, Barthélémy R, Dorze ML, Matéo J, Payen D. Reversal of neutrophilto-lymphocyte count ratio in early versus late death from septic shock. Crit Care. 2015;19(439):1-10. 